Proc. Indian Acad. Sci. (Earth Planet. Sci.), Vol. 105, No. 1, March 1996, pp. 41-61.

(C) Printed in India.

\title{
Variability of the oceanic boundary layer characteristics in the northern Bay of Bengal during MONTBLEX-90
}

\author{
V S N MURTY, Y V B SARMA and D P RAO \\ National Institute of Oceanography, Dona Paula, Goa 403004, India
}

\begin{abstract}
Variability of the ocean surface boundary layer characteristics on daily time-scale is studied utilizing the 3-hourly hydrographic data collected at a stationary location $\left(20^{\circ} \mathrm{N}\right.$, $\left.89^{\circ} \mathrm{E}\right)$ in the Bay of Bengal during August (18th $-31 \mathrm{st}$ ) and September (9th -19 th), 1990 under MONTBLEX-90 field programme. The daily variations of temperature, salinity, $\sigma_{0}$, mixed layer thickness, stability, heat content and rate of change of heat content in the upper $100 \mathrm{~m}$ are discussed in relation to prevailing weather (depressions) and hydrographic conditions (influx of fresh water, presence of eddies). The mixed layer thickness is examined through temperatureand $\sigma_{0}$-based criteria considering also the surface salinity in the latter. The $T$-based mixed layer thickness is always higher than that of $\sigma_{0}$-based thickness. The rate of change of heat content is also computed up to the depth of $20^{\circ} \mathrm{C}$ and $14^{\circ} \mathrm{C}$ isotherms which takes into account the vertical motion and hence divergence. With the development of a low into a deep depression close to the study area, intense upwelling of subsurface cold waters is noticed from $100 \mathrm{~m}$ to the bottom of the surface mixed layer $(20 \mathrm{~m})$ from 18 th to 20 th August. The upwelling is weakened by 21 st August when the depression moved away from the study location. This variation of upwelling is supported by the variation of surface mixed layer thickness, static stability at $30 \mathrm{~m}$ depth, heat content in the upper $100 \mathrm{~m}$ and the heat content up to the depth of $20^{\circ} \mathrm{C}$ isotherm from 18 th to $21 \mathrm{st}$ August. The rate of change of heat content in the upper $100 \mathrm{~m}$ and up to the depths of $20^{\circ} \mathrm{C}$ and $14^{\circ} \mathrm{C}$ isotherms leads to net heat storage during August and to net heat depletion during September. This together with the net surface heat gain lead to an import $\left(197 \mathrm{Wm}^{-2}\right)$ and export $\left(233 \mathrm{Wm}^{-2}\right)$ of heat during August and September respectively through horizontal advective processes. These advective processes are attributed to the presence and movement of a warm core eddy through the study location.
\end{abstract}

Keywords. Ocean boundary layer; Bay of Bengal; heat budget; heat content; warm core eddy; southwest monsoon; MONTBLEX-90.

\section{Introduction}

Upper oceanic boundary layer studies are important for understanding the momentum and heat energy exchanges between the ocean and overlying atmosphere. These exchange processes are further influenced by the prevailing weather disturbances. This is particularly true during southwest monsoon in the northern Bay of Bengal where many monsoon lows/depressions are formed/developed under the influence of the 'monsoon trough' which in general, lies along an axis passing through northwestern India up to the head of the Bay of Bengal. In order to understand the variability of the atmospheric as well as marine boundary layer in detail in relation to the monsoon trough (during the period of southwest monsoon of 1990 on the land and in the northern Bay of Bengal), an extensive observation program acronymed MONTBLEX (MONsoon Trough Boundary Layer EXperiment) was organized by the Department of Science and Technology (DST) in association with various national laboratories, institutions and universities. The important synoptic weather features like the shift in 
the location of the monsoon trough, cyclonic disturbances and the activity of the monsoon during the MONTBLEX-90 period have been documented by Gupta (1990). Rao and Murty (1992) studied the temporal variability of air temperature and water vapour content in the lower troposphere (up to $600 \mathrm{mb}$ ) over the northern Bay of Bengal at a stationary location utilizing the upper air data collected during MONTBLEX-90. Similarly, Sarma et al (1992) analyzed the surface meteorological data collected during the same experiment and showed that the sea surface gained heat during the observation period (18th - 31st August and 9th - 19th September, 1990) in spite of many cyclonic weather disturbances that prevailed in the study area. Murty et al (1993) studied the variability of upper $(100 \mathrm{~m})$ layer heat content and showed that the upper ocean lost $110 \mathrm{Wm}^{-2}$ of heat during 18th - 20th August, 1990 and $1000 \mathrm{Wm}^{-2}$ during 12th -13 th September, 1990 under the influence of depression/low during these periods. In addition, the presence of meso-scale eddies in the Bay of Bengal (Swallow 1983; Cutler and Swallow 1984; Rao et al 1987; Babu et al 1991) would also contribute to the variability in the heat and salt contents of the upper ocean. In this paper, we examine the temporal variability of the oceanic boundary layer characteristics in the northern Bay of Bengal during MONTBLEX-90 in relation to the prevailing weather and hydrographic conditions.

\section{Data and methodology}

The water temperature and salinity data collected using CTD probe (make: Sea Bird model SBE-11, USA) at 3-hourly intervals in the northern Bay of Bengal at a stationary location $\left(20^{\circ} \mathrm{N}, 89^{\circ} \mathrm{E}\right.$; figure 1$)$ onboard ORV Sagarkanya during the southwest monsoon period (18th-31st August and 9th-19th September) of 1990 under MONTBLEX-90 programme have been utilized. The accuracies of the CTD temperature and salinity sensors are $\pm 0.005^{\circ} \mathrm{C}$ and \pm 0.002 PSU (Practical Salinity Unit) respectively. The data quality control procedures are detailed in Anon (1990). The daily averages of temperature,

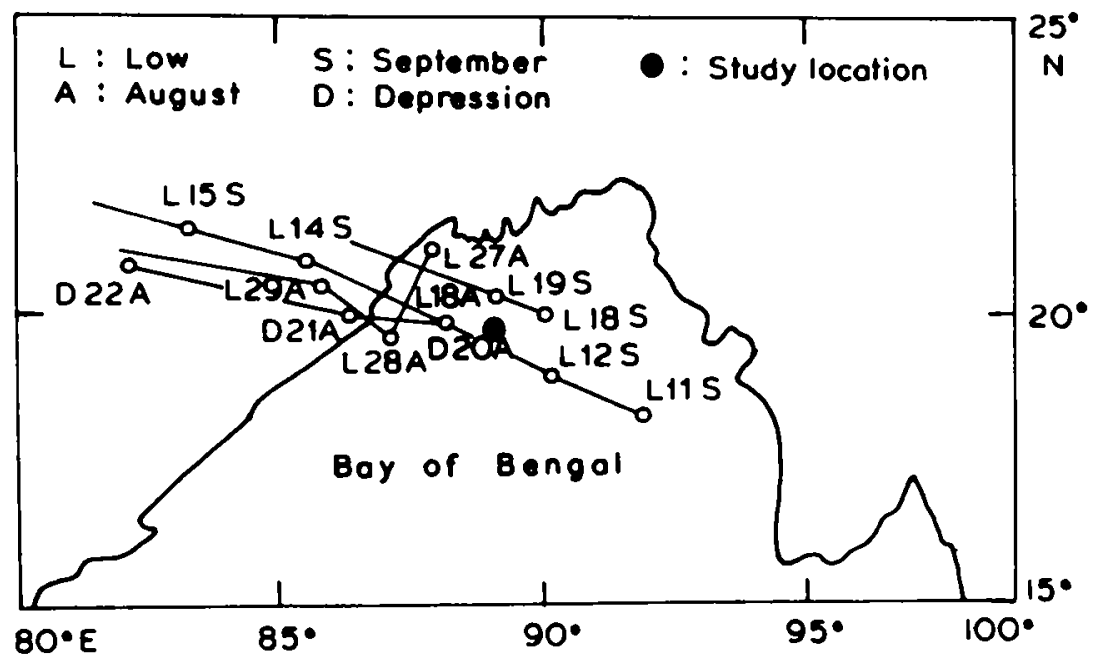

Figure 1. Area of study with trajectories of depressions. 
salinity and $\sigma_{\theta}$ are obtained for the upper $100 \mathrm{~m}$ depth during August and September. The thickness of the surface mixed layer is obtained through two criteria. In the first criterion (temperature based) the thickness of the mixed layer is chosen as the depth where the water temperature is less by $1{ }^{\circ} \mathrm{C}$ from the sea surface temperature following Murty et al (1992). Since the study area comes under the influence of a huge influx of fresh water and precipitation during the southwest monsoon, considerable variations in the salinity field occur which in turn affect the upper layer stratification thereby the mixed layer thickness. Hence, an alternative criterion based on $\sigma_{\theta}$ variation is adopted (Suga and Hanawa 1990) for determining the thickness of the surface mixed layer. This is the depth where the density is the surface density plus a chosen value. The chosen value is the increment in density obtained when the surface temperature is reduced by $1^{\circ} \mathrm{C}$ with salinity held constant.

The water stability $(E)$ in terms of the Brunt-Vaisala frequency is computed from the changes in the daily averages of in situ density over a $10 \mathrm{~m}$ thick slab using the following equation (Pollack 1954):

$$
E=g / \bar{\rho}\left[\mathrm{d} \rho / \mathrm{d} z-g \bar{\rho} / C^{2}\right]
$$

where $g$ is the acceleration due to gravity $\left(9.8 \mathrm{~ms}^{-2}\right), \rho$ is the sea water density $\left(\mathrm{kgm}^{-3}\right)$, $\bar{\rho}$ is the mean density in the water column of $\mathrm{d} z, z$ is the depth $(\mathrm{m})$ and $C$ is the sound velocity $\left(\mathrm{ms}^{-1}\right)$ in sea water (Chen and Millero 1977).

The heat content of the upper water column is computed up to the fixed depth $(100 \mathrm{~m})$ and up to the depths of $20^{\circ} \mathrm{C}$ and $14^{\circ} \mathrm{C}$ isotherms using the following equation:

$$
H C=\bar{\rho} C_{p} \int_{0}^{D} \Delta T \mathrm{~d} z,
$$

where $C_{p}$ is specific heat of sea water at constant pressure, $\Delta T$ is mean temperature of the layer of thickness $\mathrm{d} z$ and $D$ is the depth of the water column considered. The heat content above the chosen isotherm which takes into account the vertical motion and hence divergence in the water column (Emery 1975) is useful for the upper layer heat budget and correlates well with the net heat flux at the sea surface.

From the daily mean values of $H C$, the rate of change of heat content is estimated as:

$$
H S=\mathrm{d} H C / \mathrm{d} t=\left(H C_{(i+1)}-H C_{i}\right) /(24 \times 3600),
$$

where the subscript ' $i$ ' represents the day.

\section{Results and discussion}

\subsection{Salient weather features}

The weather during 18 th - 25th August is dominated by monsoon depressions and low pressure systems over the north/northwestern Bay (Gupta 1990). A low was formed on 18 th August about $150 \mathrm{~km}$ to the west of the study location and developed there into a deep depression by the 20th and crossed the coast near Daradeep on the morning of $21 \mathrm{st}$ (figure 1). The monsoon trough shifted to the foot of the Himalayas during 24th - 26th August and shifted southward during 27th -30 th August. During 10th -11 th September 
temporary northward shift of the monsoon trough was noticed and during 12 th -13 th September a low passed over the study area (figure 1).

\subsection{Surface meteorological conditions}

The influence of the above weather conditions is clearly reflected in the daily variation of the surface wind field during August and September (figures $2 a$ and $2 b$ ). With the development of deep depression the wind speed increased from $2 \mathrm{~m} / \mathrm{s}$ on 18 th August to $8 \mathrm{~m} / \mathrm{s}$ on 20 th August (figure 2a). The direction of wind was southwesterly initially, but under the influence of the deep depression exhibited a variation from southwesterly to southeasterly and southerly. With the northward shift of the monsoon trough the wind speed showed a gradual decrease from 21st to 26th August. A second maximum in wind speed with southerly direction was noticed on 29 th August when the monsoon trough extended southward. During September also the higher speeds were associated with southerly winds (figure $2 \mathrm{~b}$ ) under the influence of a passing low.

The daily march of latent heat flux $\left(Q_{E}\right)$ and the net heat flux $\left(Q_{N}\right)$ at the sea surface during August (figure 3a) exhibited variations in accordance with the above weather conditions. Large latent heat flux $\left(140 \mathrm{Wm}^{-2}\right)$ and lower $\left(60 \mathrm{Wm}^{-2}\right)$ net heat gain (positive heat flux) occurred at the time of deep depression. It is also seen that the heat gain is decreased by about $80 \mathrm{Wm}^{-2}$ from 18 th to 20 th August due to enhancement of latent heat flux by similar magnitude during the same period. As the monsoon trough moved northward the latent heat flux decreased and hence the net heat gain increased. Similarly with the southward shift of the monsoon trough the latent heat flux picked up and the net heat gain exhibited a decrease from 27th to 31st August. During September also, the latent heat flux and the net heat flux exhibited variations due to the prevailing weather conditions.

\subsection{Temperature}

The daily variation of temperature at selected depth levels (surface, 10, 30, 50,75, $100 \mathrm{~m}$ ) in the upper $100 \mathrm{~m}$ is shown in figures $4 \mathrm{a}$ and $4 \mathrm{~b}$ for August and September respectively. The SST showed a gradual decrease of about $0.3^{\circ} \mathrm{C}$ from $29 \cdot 1^{\circ} \mathrm{C}$ to $28.8^{\circ} \mathrm{C}$ under the influence of the low and deep depression from 18th to 21st August (figure 4a). The influence of this weather disturbance is felt up to a depth as deep as $100 \mathrm{~m}$ as seen from relatively lower temperatures up to $100 \mathrm{~m}$ depth from 18 th to $22 \mathrm{nd}$ August. These lower temperatures are due to intense upwelling of cold waters in the upper $100 \mathrm{~m}$ water column. Gopalakrishna et al (1993) also reported storm-induced upwelling from about $80 \mathrm{~m}$ depth at a distance of around $110 \mathrm{~km}$ from the storm-centre. The slightly higher temperature differences between the surface and $30 \mathrm{~m}$ on 18th and 19th August are clearly due to the upwelling reaching the sea surface. After the disappearance of the depression from the study area, the SST slowly increased to $29.1^{\circ} \mathrm{C}$ by 25 th August coinciding with the northward shift of the monsoon trough and consequent increase in net surface heat flux. With the increase of net heat gain and the reduction in the turbulent mixing due to winds, the temperature difference (between surface and $30 \mathrm{~m}$ ) becomes minimum and leads to a thick isothermal layer occupying the top $30 \mathrm{~m}$ between 22nd and 31st August. Below this layer, the temperature increased rather rapidly from 22nd to 28th August at all the depth levels. 


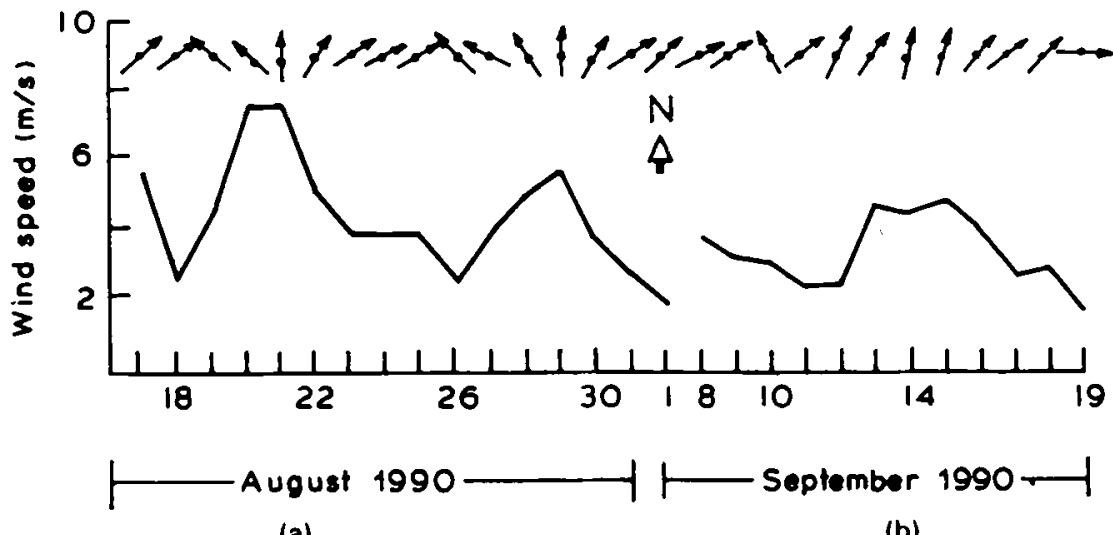

(a)

(b)

Figure 2. Variation of surface wind field during MONTBLEX-90 for August and September.

In September, the thick surface isothermal layer continued till the end of the observation period (figure 4b). Below this layer the temperature showed a gradual decrease from 11 th to 17 th at $50 \mathrm{~m}$ and $75 \mathrm{~m}$ depths. The temperature difference between surface and $50 \mathrm{~m}$ is low from 9 th to 12 th September and gradually increased to a higher value on 18 th September. At $100 \mathrm{~m}$ the temperature varied between $21^{\circ} \mathrm{C}$ and $22^{\circ} \mathrm{C}$.

While the decrease of SST is $0.2^{\circ} \mathrm{C}$ under the influence of a deep depression that developed close to the study area, the decrease of SST is $0 \cdot 1^{\circ} \mathrm{C}$ when a low passed over the study area (12th -13 th September).

\subsection{Salinity}

In August, the daily variation of salinity shows a thin $(10 \mathrm{~m})$ isohaline layer in the top $10 \mathrm{~m}$ water column with its salinity increasing gradually from 31.9 PSU on 18 th to 33.2 PSU on 26th August and then decreasing to $32 \cdot 2$ PSU by 31 st August (figure Sa). The low salinity on 18 th is due to the influence of fresh water influx from the northern Bay against the prevailing southwesterlies. The increase of salinity of the isohaline layer from 18 th to 26 th August could be due to mixing between the less saline fresh water and the relatively saline waters moving northward from the south of the study location (Murty et al 1992) under the influence of strong southeasterly/southerly winds associated with the depression and persistence of mixing after the cessation of strong winds. Large salinity differences are noticed from surface to $30 \mathrm{~m}$ depth on 18 th only due to overlying low-salinity waters. At and below $30 \mathrm{~m}$, salinity is slightly high (compared to the salinity on the next few days) from 18 th to 21 st supporting the upward movement of subsurface saline waters during the intense upwelling process as mentioned above. At $100 \mathrm{~m}$ salinity is uniform at 34.9 PSU. The minimum salinity difference between surface and $30 \mathrm{~m}$ depth from 23rd to 29th August suggests the thickening of the surface isohaline layer which is characterized by relatively high salinity. 

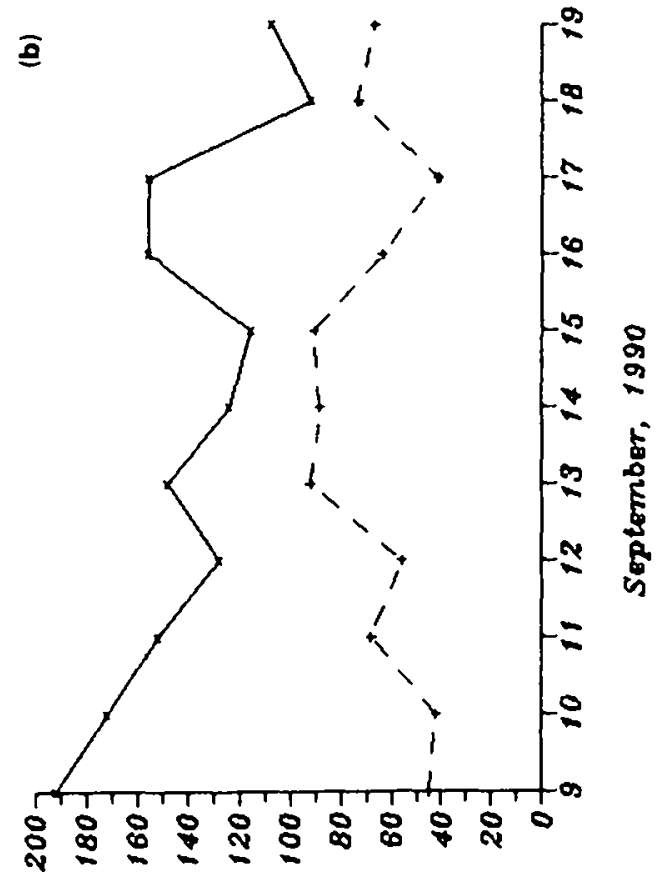

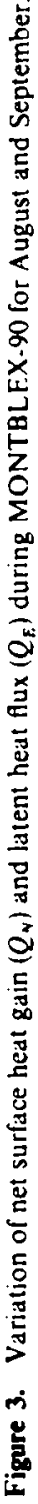

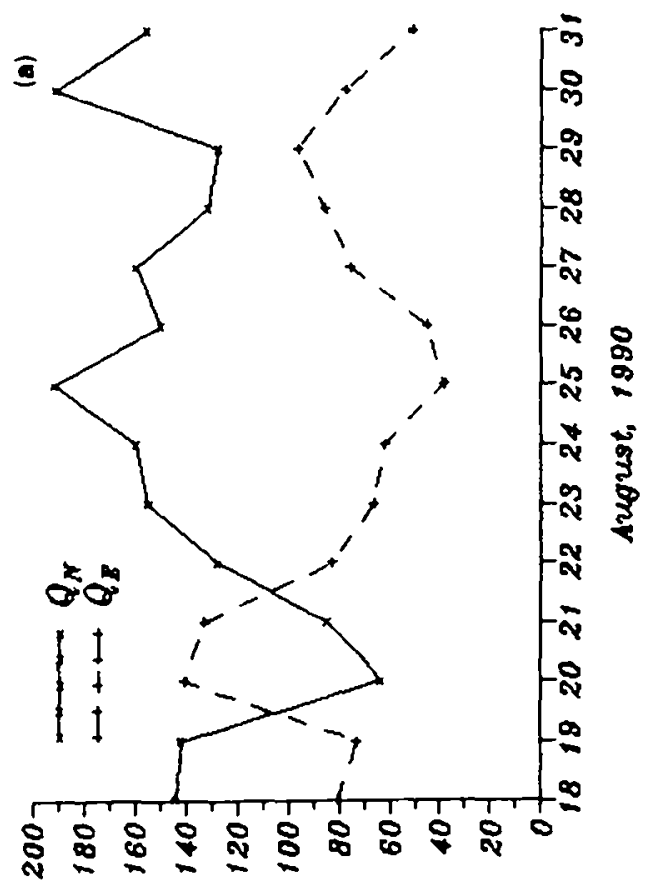

$(z u / a) x+1 / 20 a H$ 
$\underline{\underline{\underline{e}}}$

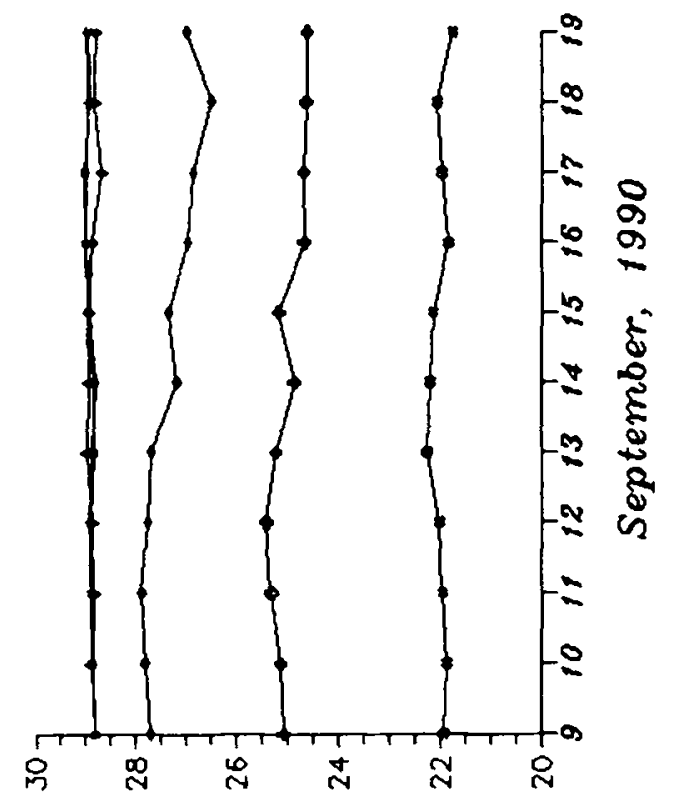

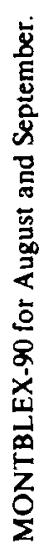

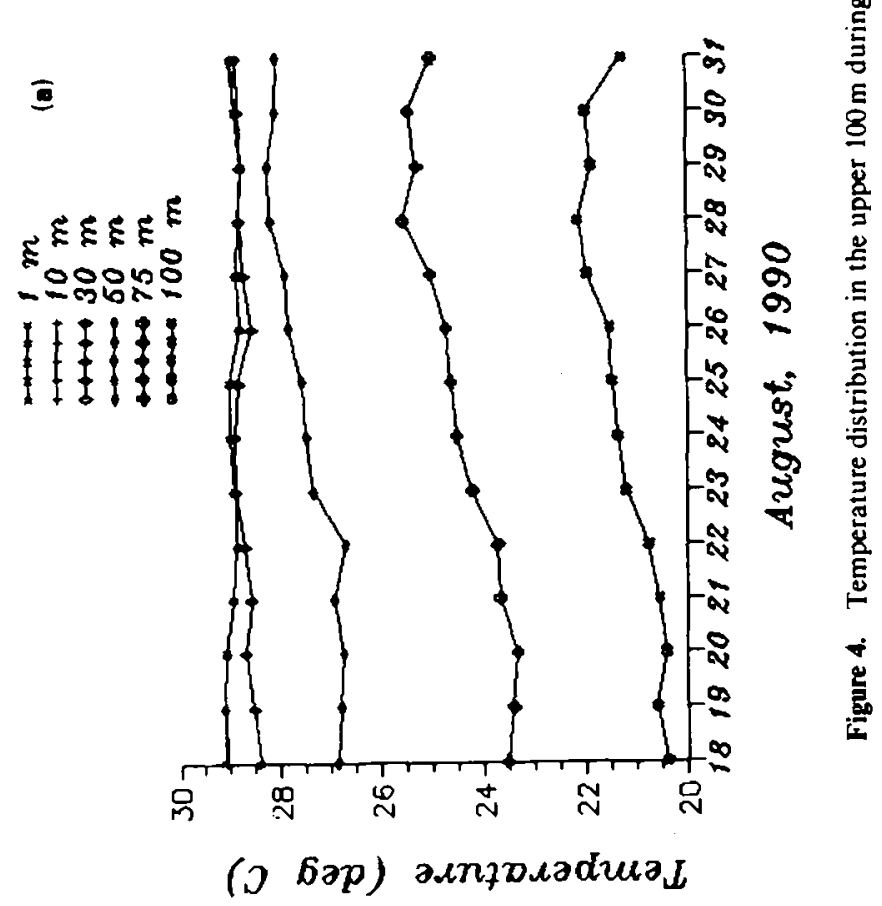




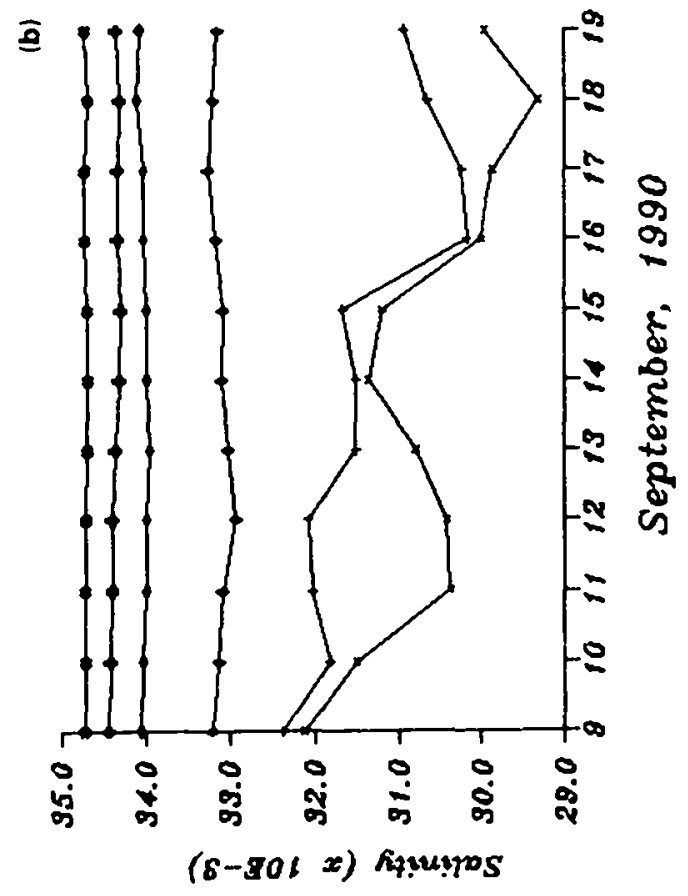

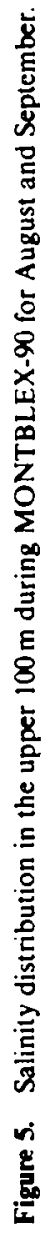
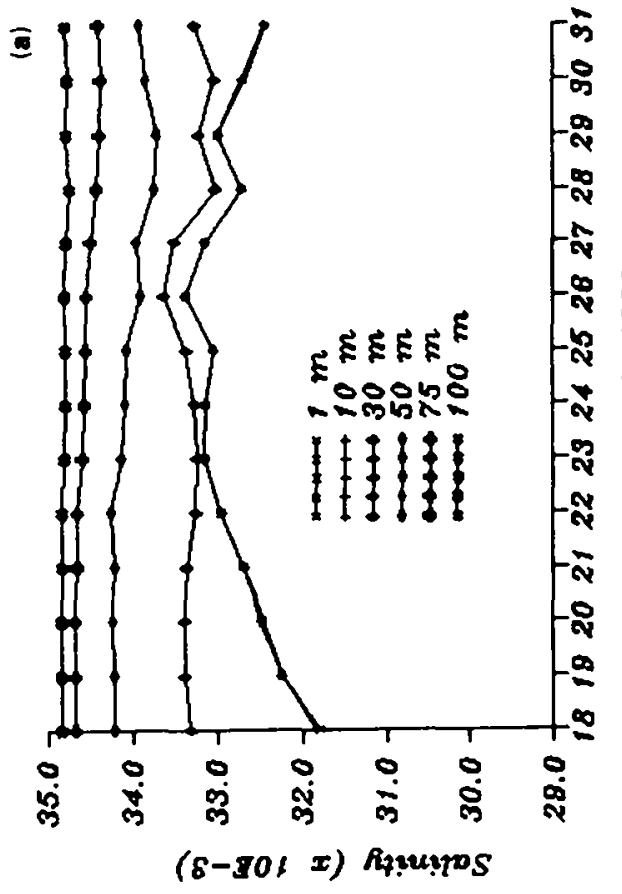
During September, a decrease of salinity in the top $10 \mathrm{~m}$ is clearly seen from 9 th to 18th September coinciding with the period of the passing of a low and the relatively higher speeds of southwesterly/southerly winds (figure 5b). The salinity distribution at the surface and $10 \mathrm{~m}$ indicates greater influx of fresh water towards the study location when compared to that in the top $10 \mathrm{~m}$ during August. The occurrence of slightly saline waters in the top $10 \mathrm{~m}$ from 13 th to 15 th September indicates the northward movement of southern saline waters and their mixing with the fresh waters of the north Bay.

The fresh waters at the study location are in general noticed at the times of lower winds both during August and September, though the southwesterly winds persisted. It can be noted that in general the thin isohaline layer is embedded within the thick $(30 \mathrm{~m})$ surface isothermal layer. At and below $30 \mathrm{~m}$ depth, the daily variations of salinity are small.

\subsection{Density anomaly $\left(\sigma_{\theta}\right)$}

In the upper $30 \mathrm{~m}$, the density variations are very closely related to the salinity variations both in August and September (figures 6a and 6b). Below $30 \mathrm{~m}$, the dominant influence of temperature on the density distribution is noticed as salinity variations become small. The occurrence of denser waters at subsurface depths from 18 th to 22 nd August could largely be due to the intense upwelling processes under the influence of the development of a deep depression close to the study area. The decrease in density at $50 \mathrm{~m}, 75 \mathrm{~m}$ and $100 \mathrm{~m}$ depths from $22 \mathrm{nd}$ to 29 th August indicates the presence of warm waters at these depths.

\subsection{Mixed layer thickness (MLT)}

The MLT obtained through the $\sigma_{\theta}$-based criterion is lower than that obtained by the $T$-based criterion. The large differences between the two MLTs become more clear from the scatter plots (figures $7 \mathrm{a}$ and $7 \mathrm{~b}$ ) of the mixed layer thicknesses computed following the two criteria. During August, two types of clusters can be seen in the scatter plot (figure 7a); one cluster shows near linear relation when the fresh water influx is insignificant while the second cluster exhibits large scatter indicating the effect of stratification on $\sigma_{\theta}$-based MLT. During September, the influx of fresh water has dramatically worsened the relation between the MLTs with $\sigma_{\theta}$-based MLT remaining much lower than the T-based MLT. This underlines the importance of stratification in the northern Bay of Bengal in the mixed layer dynamics; any effort to model the mixed layer should invariably include salinity.

The daily variation of MLT during August and September is shown in figures 8a and $8 \mathrm{~b}$ respectively. In August, both the criteria showed lower MLTs on 18 th and increased. very little by 20 th August. The $\sigma_{\theta}$-based MLT increased steeply to about $32 \mathrm{~m}$ from $21 \mathrm{st}$ to 24th August when wind speed exhibited a decrease. The variation of $\sigma_{\theta}$-based MLT is in accordance with the wind speed between 27 th and 31st August. The $\sigma_{\theta}$-based MLT can be considered as the layer of dominant turbulent mixing due to winds at the surface as it coincided nearly with the thickness of the surface isothermal layer. In that case, the lower MLTs from 18th to 20th August indicate the dominance of the upwelling process over the turbulent mixing, though winds are strong during this period under the influence of the developing deep depression. The $T$-based MLT exhibited a gradual 


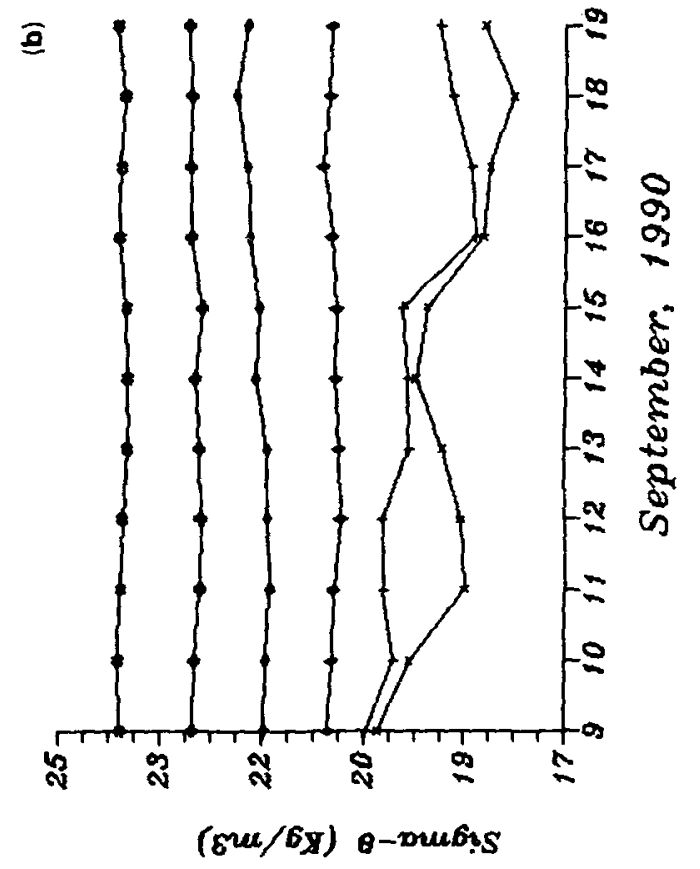

|0

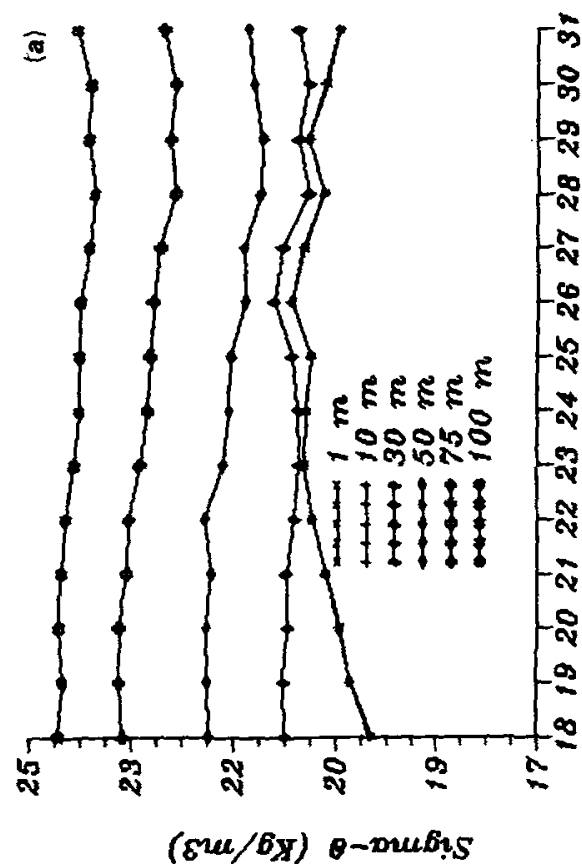

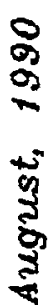


우
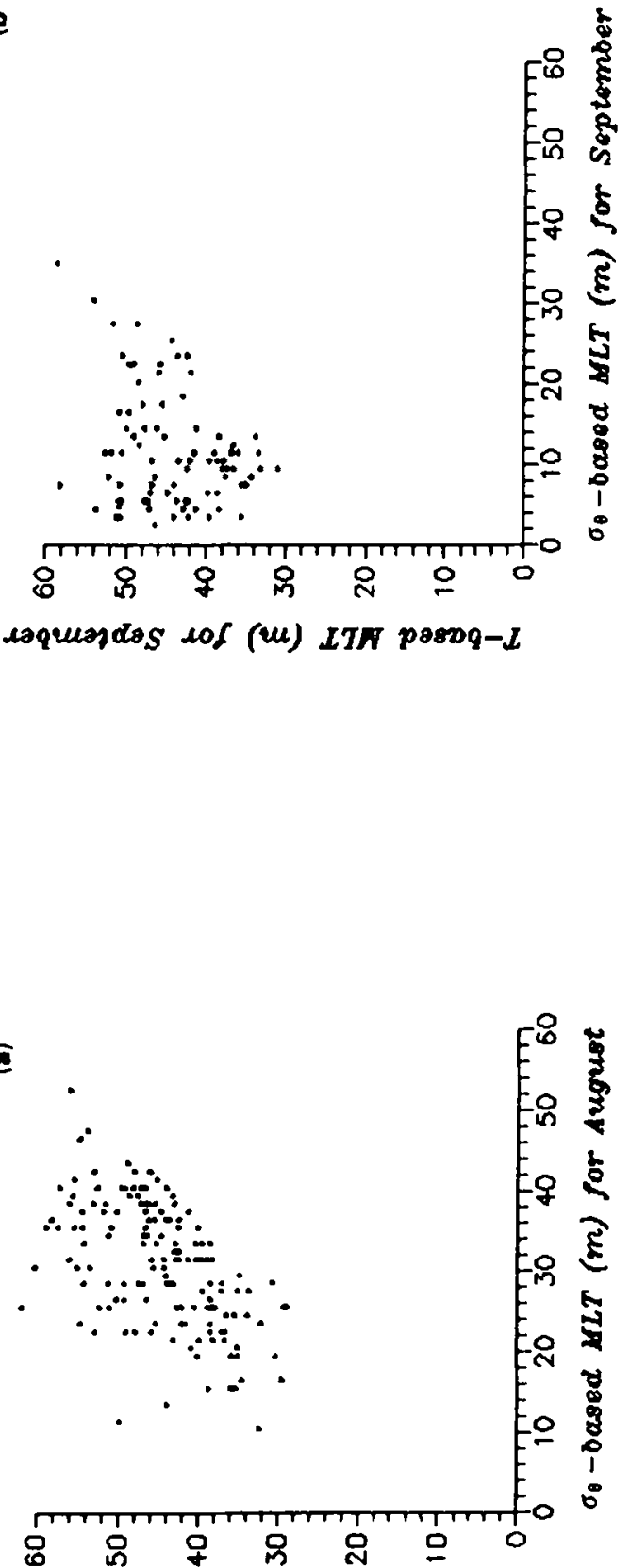

zsnonp cos (u) LTH paswq-L 
อ

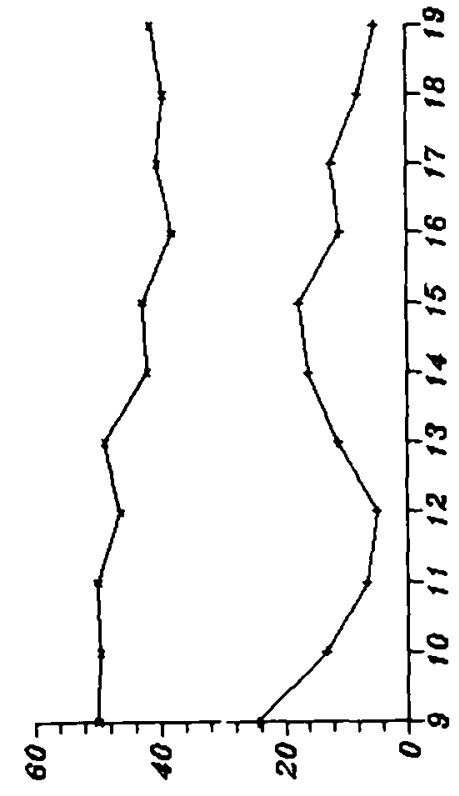

(ui) 8souryogy coftpl pax?

$\Xi$

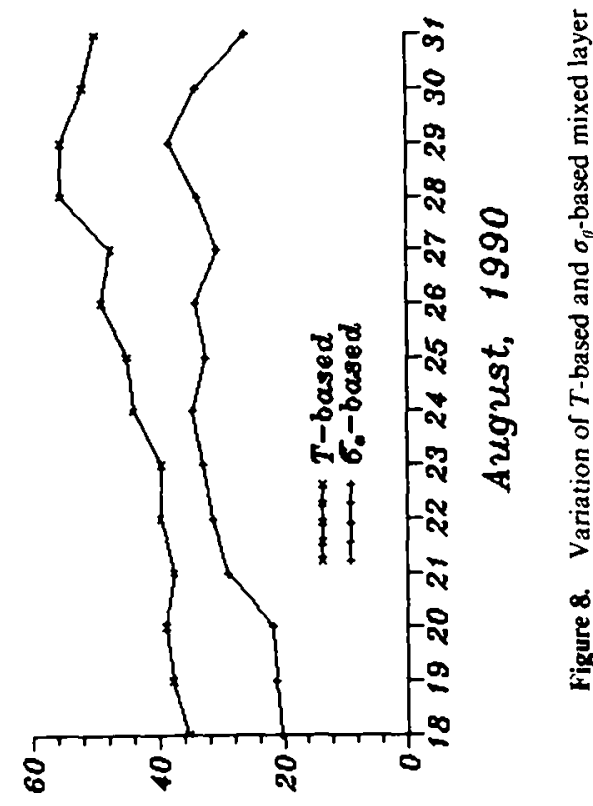

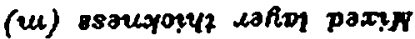

क

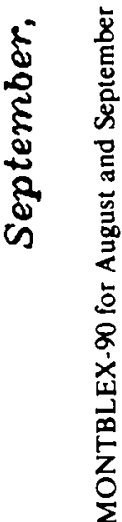

㝕

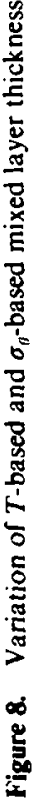


increase from 21st to 29th August and the differences in both the MLTs increased beyond 24th August. The increase of $T$-based MLT indicates warming below the $\sigma_{\theta}$-based mixed layer.

During September, the $\sigma_{\theta}$-based MLT variation is in accordance with the wind speeds at the surface. The higher the wind speeds the higher the $\sigma_{\theta}$-based MLT. Also, on the days of fresh water influx the MLT is low. The $\sigma_{\theta}$-based MLT decreased from $24 \mathrm{~m}$ on 9 th September (figure $8 \mathrm{~b}$ ) to $6 \mathrm{~m}$ on 11 th September in association with low salinity waters at the surface. The increase of MLT during 12th - 14th September is due to vertical mixing under the influence of higher winds of the passing low. One can notice large differences between $\sigma_{\theta}$-based and $T$-based MLTs though the latter exhibits a gradual decrease. This decrease in T-based MLT indicates the cooling below the $\sigma_{\theta}$-based mixed layer as SST was stable throughout the period from 9 th to 19 th September.

\subsection{Stability}

The stability of the water column over a $10 \mathrm{~m}$ slab at various depth levels is shown in figures $9 \mathrm{a}$ and $9 \mathrm{~b}$ for August and September respectively. In August, very low stability is noticed at $10 \mathrm{~m}$ depth as this depth lies within the surface mixed layer (figure 9a) in which vertical gradients of density are low. The stability is considerably high $\left(9.5 \times 10^{-4} \mathrm{~s}^{-2}\right)$ on 18 th at $30 \mathrm{~m}$ depth $\left(25-35 \mathrm{~m}\right.$ slab) just below the $\sigma_{\theta}$-based MLT and is associated with intense upwelling of colder waters giving rise to higher vertical density gradients. This higher stability at $30 \mathrm{~m}$ restricts the upwelling effect reaching the sea surface. The rapid decrease of stability at $30 \mathrm{~m}$ depth after 18 th August is followed by an increase of stability at $50 \mathrm{~m}$ depth indicating the deepening of the mixed layer thickness. This suggests that the turbulent mixing is strong and influences a deeper water column. At $75 \mathrm{~m}$ and $100 \mathrm{~m}$ depths the stability is relatively lower than that at $50 \mathrm{~m}$ depth. This shows that the vertical density gradients are lower at these depths compared to those at $50 \mathrm{~m}$. These weak density gradients must be due to warming at subsurface depths suggesting the active role of horizontal advective processes.

During September, the stability at $10 \mathrm{~m}$ and $30 \mathrm{~m}$ depths exhibited opposite variation (figure $9 \mathrm{~b}$ ) and their daily variation is closely related to the daily variation of mixed layer thickness. The high variability in stability at $10 \mathrm{~m}$ is a result from the large density gradients generated by freshwater influx. The stability at $50 \mathrm{~m}, 75 \mathrm{~m}$ and $100 \mathrm{~m}$ depths varied within a narrow range and the stability at $100 \mathrm{~m}$ lies in between that at $50 \mathrm{~m}$ and $75 \mathrm{~m}$ depths. The gradual increase of stability at $100 \mathrm{~m}$ from 13 th to 19 th September suggests the increase in vertical density gradients which in turn shows that the horizontal advective processes are dominant.

\subsection{Upper layer heat content}

Figures $10 \mathrm{a}$ and $10 \mathrm{~b}$ represent the daily variation of upper layer heat content during August and September respectively. In August, the upper layer heat content is low $\left(109 \times 10^{8} \mathrm{Jm}^{-2}\right)$ from 18 th to $22 \mathrm{nd}$ and exhibits a decrease by about $0.2 \times 10^{8} \mathrm{Jm}^{-2}$ from 18 th to 20 th under the influence of the development of the deep depression. The corresponding heat loss would be about $110 \mathrm{Wm}^{-2}$ in 48 hours. It appears that this heat loss has been utilized for the enhancement of latent heat flux by nearly up to the same magnitude at the air-sea interface during 18th to 20th August (figure 3a), 


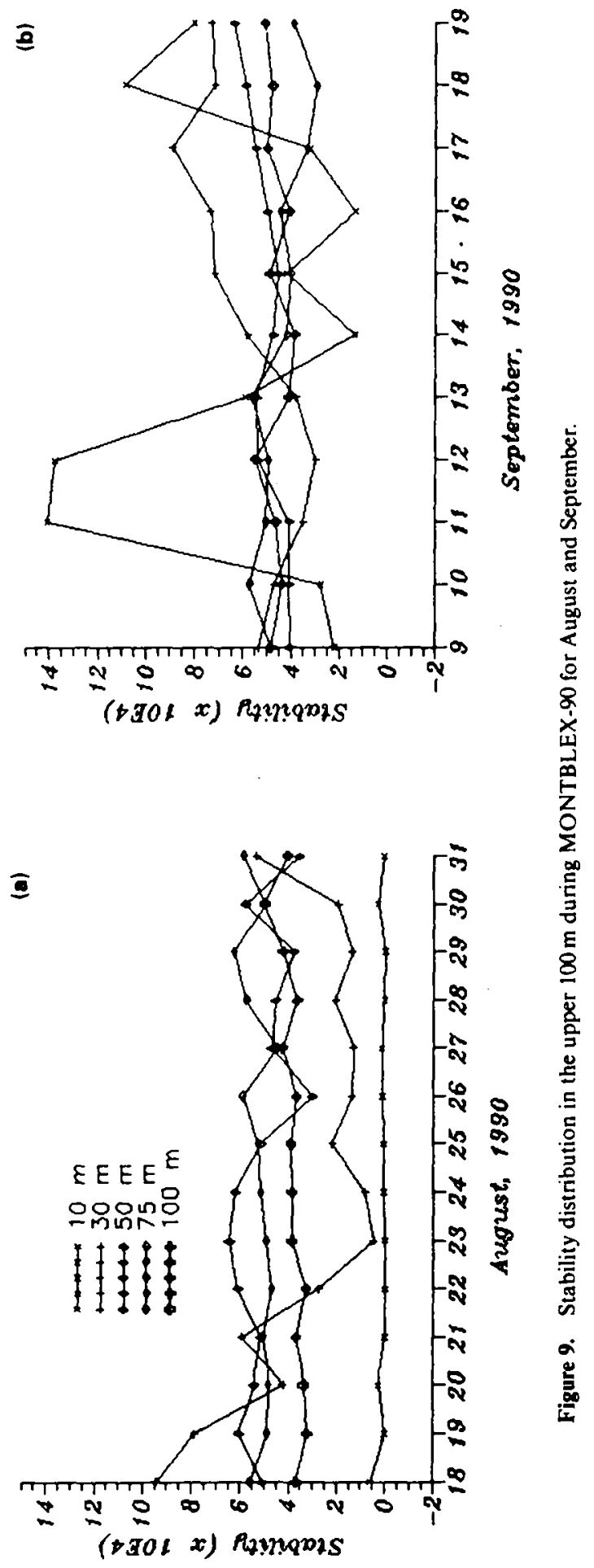


$\underline{\underline{a}}$

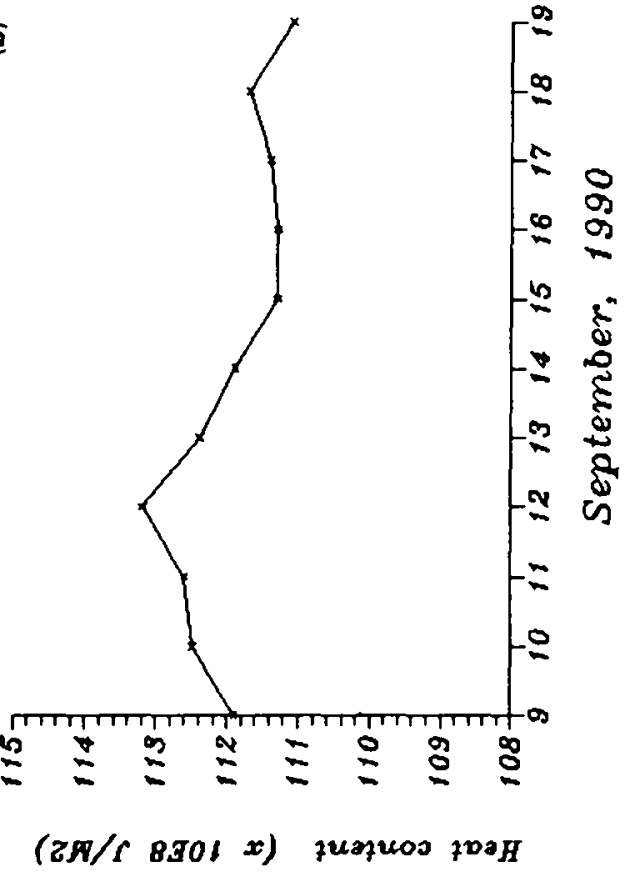

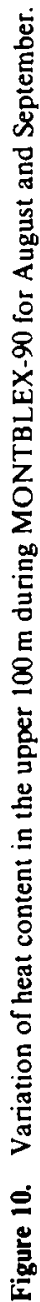

]

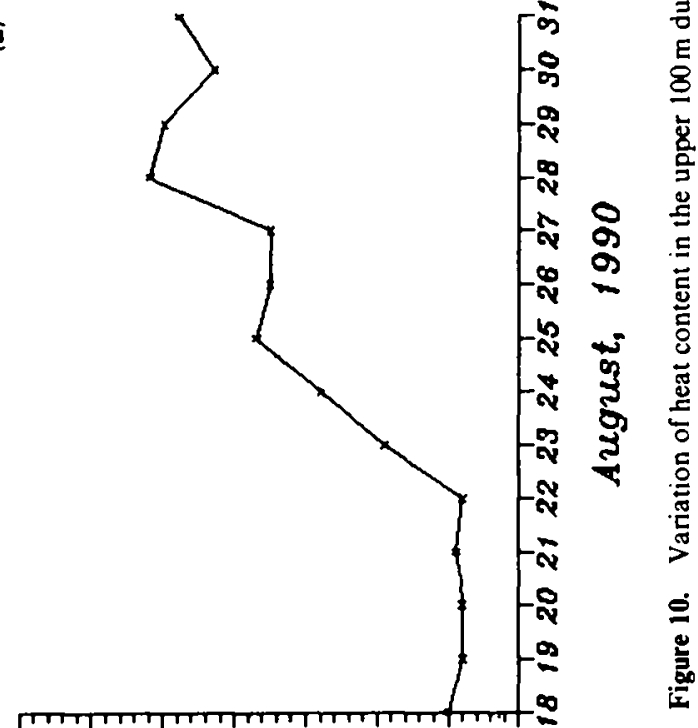<smiles>C1CCCCCCCCCCCCCCCC1</smiles>

के

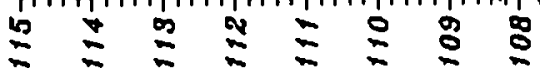

$(z R / C$ 8gO/ x) zuazuoo $200 H$ 
suggesting that the air-sea interaction is active with a positive feed-back from sea to air in the study area during this period. The heat content is invariant for the next two days, i.e. from 20th to 22nd August, and increased rapidly from 23rd to 25th August and gradually thereafter.

During September, the heat content in the upper layer increases from $111.8 \times 10^{8} \mathrm{Jm}^{-2}$ on 9 th to $113.5 \times 10^{8} \mathrm{Jm}^{-2}$ on 12 th September (figure 10b). It has decreased rapidly by 13 th September when a low passed over the study location. However, the decrease of heat content is continued for the next two days, i.e. from 13th to 15 th September, and exhibited an increase beyond 15th September.

When the variation of the upper layer heat content during August and September is examined in relation to the net heat flux at the sea surface during August and September, it is noticed that the increase (decrease) in the heat content is not entirely due to the increase (decrease) of net surface heat gain. It is also seen that the decrease of heat content at the time of depression and low is continued up to the next two days both during August and September. Further, at the time of decrease in the net heat gain the upper layer heat content is increased.

\subsection{Rate change of upper layer heat content}

The daily variations of rate of change of upper layer heat content during August and September are shown in figures $11 \mathrm{a}$ and $11 \mathrm{~b}$ respectively. The surface layer loses (negative values) heat energy initially from 18 th to 19 th August and gains (positive) heat energy from 20th to 21st August due to the development of deep depression. This shows that the intense upwelling on 18 th is weakened by 21 st. Heat gain is dominant from 22nd to 28th August.

During September, heat gain in the upper layer is noticed initially and heat loss dominates from 12 th to 15 th. This is followed by weak heat gain and subsequently heat loss.

The mean values of the net heat flux $\left(Q_{N}\right)$ at the sea surface, the rate of change of heat content up to a fixed depth of $100 \mathrm{~m}\left(Q_{T}\right)$, up to the depth of $20^{\circ} \mathrm{C}$ isotherm $\left(Q_{T 20}\right)$ and up to the depth of $14^{\circ} \mathrm{C}$ isotherm $\left(Q_{T 14}\right)$ for August and September are presented in table 1. During August the $20^{\circ} \mathrm{C}$ isotherm varied between $103 \mathrm{~m}$ and $117 \mathrm{~m}$ with the mean temperature of the column up to this isotherm varying from $25.55^{\circ} \mathrm{C}$ to $26 \cdot 19^{\circ} \mathrm{C}$. During September the $20^{\circ} \mathrm{C}$ isotherm varied between $107 \mathrm{~m}$ and $122 \mathrm{~m}$ with the mean temperature of the column varying from $25.66^{\circ} \mathrm{C}$ to $25.93^{\circ} \mathrm{C}$. From the table, it is noticed that the sea surface gains heat energy to the tune of $141 \mathrm{Wm}^{-2}$ both during August and September. The rate of change of heat content up to $100 \mathrm{~m}$ depth, however, indicates that the water column experiences a heat gain of $338 \mathrm{Wm}^{-2}$ during August and heat loss of $93 \mathrm{Wm}^{-2}$ during September. The rate of change of heat content computed up to the depth of $20^{\circ} \mathrm{C}$ isotherm $\left(Q_{T 20}\right)$ also shows a heat gain of about $950 \mathrm{Wm}^{-2}$ during August and a heat loss of $170 \mathrm{Wm}^{-2}$ during September. Extending the computations up to the depth of $14^{\circ} \mathrm{C}$ isotherm $\left(Q_{T 14}\right)$ also resulted in a heat gain during August and heat loss during September respectively.

The above mean values reveal that the water column considered receives excess heat energy over the net heat input at the surface during August and gives away more heat energy during September, though there is a net heat input at the surface. This suggests that there is import of heat towards the study location and export of heat from the study 
Oceanic boundary layer characteristics

로

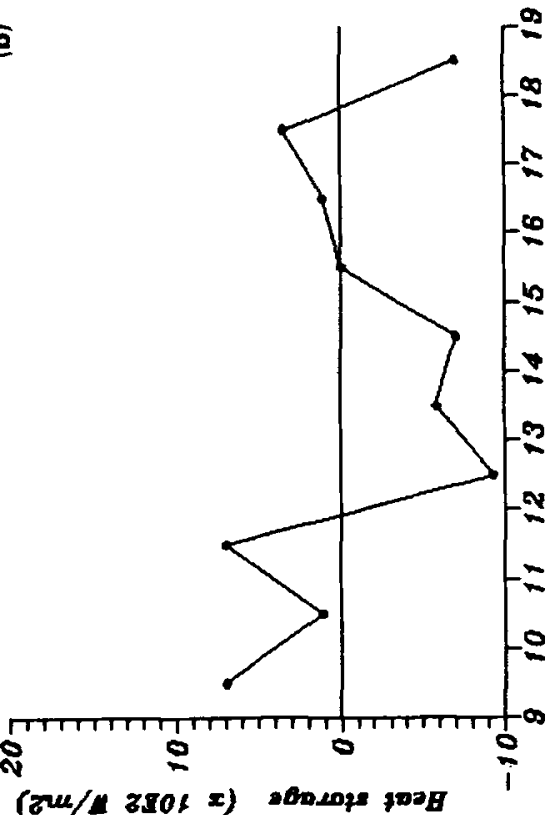

0 )

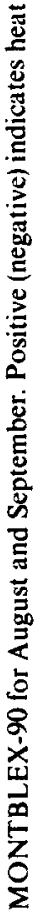

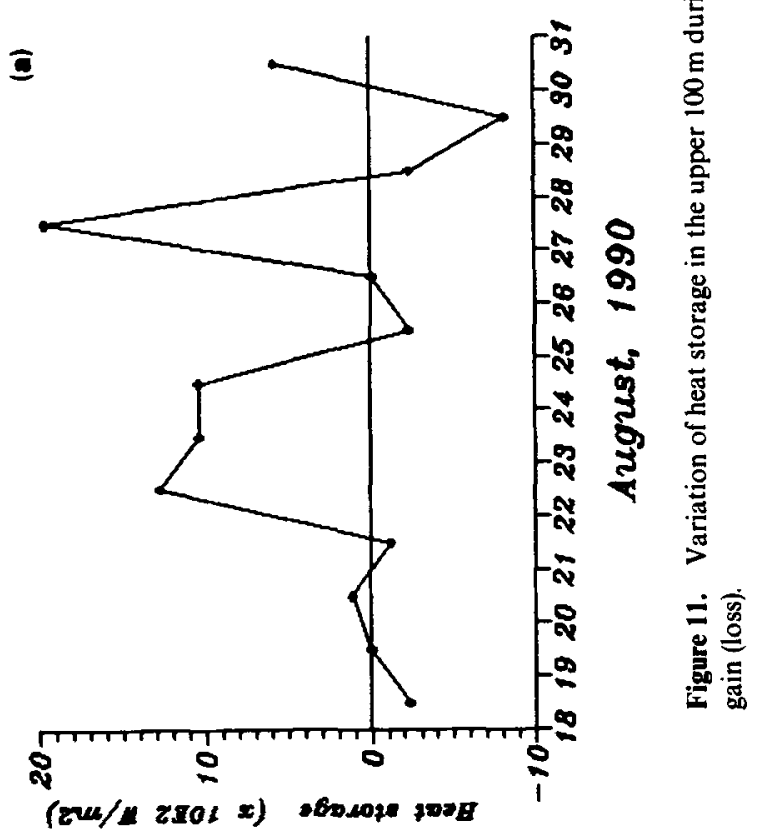


Table 1. Upper ocean heat budget in the northern Bay of Bengal during southwest monsoon of $1990\left(Q_{N}-\right.$ net surface heat gain at the sea surface; $Q_{T}$ - net heat storage in the upper $100 \mathrm{~m} ; Q_{A}$ - heat import (+ve)/export $(-\mathrm{ve})$ due to lateral advective processes in the upper $100 \mathrm{~m}$; $Q_{T 20}$ - net heat storage up to the depth of $20^{\circ} \mathrm{C}$ isotherm; and $Q_{T 14}$ - net heat storage up to the depth of $14^{\circ} \mathrm{C}$ isotherm), Units.: $\mathrm{Wm}^{-2}$

\begin{tabular}{lcc}
\hline $\begin{array}{l}\text { Heat budget } \\
\text { parameters }\end{array}$ & August & September \\
\hline$Q_{N}$ & 141 & 140 \\
$Q_{T}$ & 338 & -92 \\
$Q_{A}$ & 197 & -233 \\
$Q_{T 20}$ & 950 & -169 \\
$Q_{T 14}$ & 1039 & -427 \\
\hline
\end{tabular}

location due to lateral advective processes. On an annual scale the net heat input at the surface may be balanced by lateral heat export leaving out no local heat storage in the water column (Hastenrath and Lamb 1979a). However, on the seasonal or on shorter time scales it can be realised that the net heat gain at the sea surface $\left(Q_{N}\right)$ will be utilized for the local heat storage $\left(Q_{T}\right)$ and lateral heat export or import $\left(Q_{A}\right)$ within the ocean (Hastenrath and Lamb 1979a), thus $Q_{N}=Q_{T}+Q_{A}$. From the mean values of $Q_{N}$ and $Q_{T}$ it can be estimated that the heat import during August amounts to $197 \mathrm{Wm}^{-2}$ and heat export of $233 \mathrm{Wm}^{-2}$ during September due to lateral advective processes (table 1 ) in the upper $100 \mathrm{~m}$ water column. Similarly, the $Q_{T 20}$ and $Q_{T 14}$ also indicate heat import during August and heat export during September, however with larger magnitudes compared to those in the upper $100 \mathrm{~m}$ water column. This shows that the trend of heat import during August and heat export during September are not altered even if the heat content computations were carried out up to a fixed depth level $(100 \mathrm{~m})$ or up to the depth of an isotherm, though the latter case takes into account the vertical movement of the isotherm and hence the vertical motion and the divergence in the water column above an isotherm. This suggests that the estimated heat import and export are mainly due to the lateral advective processes.

The above estimated heat import and export could be substantiated from the abrupt increase of mean temperature of the upper $100 \mathrm{~m}$ by about $0.8^{\circ} \mathrm{C}$ from 22 nd August to 13 th September and a decrease by about $0 \cdot 2^{\circ} \mathrm{C}$ thereafter (figures $12 \mathrm{a}$ and $12 \mathrm{~b}$ ). The depths of the $26^{\circ} \mathrm{C}$ isotherm and 34.0 PSU isohaline have also shown a gradual deepening from 22nd August to 13th September and a gradual shoaling thereafter (figures $12 \mathrm{c}$ and 12d). A critical examination of the vertical movement of isotherms and isohalines in the upper $200 \mathrm{~m}$ water column during August and September reveals a similar trend of variation as that of the $26^{\circ} \mathrm{C}$ isotherm and 34.0 PSU isohaline. From these figures one can safely assume that the mean depths of occurrence of the isotherms and isohalines remained more or less unchanged from 31st August to 8th September though no data were available during this period. This observed deepening of isotherms and isohalines from 22nd August to 13th September indicates the advection of warm and less saline waters into the study area during this period which also gets its 

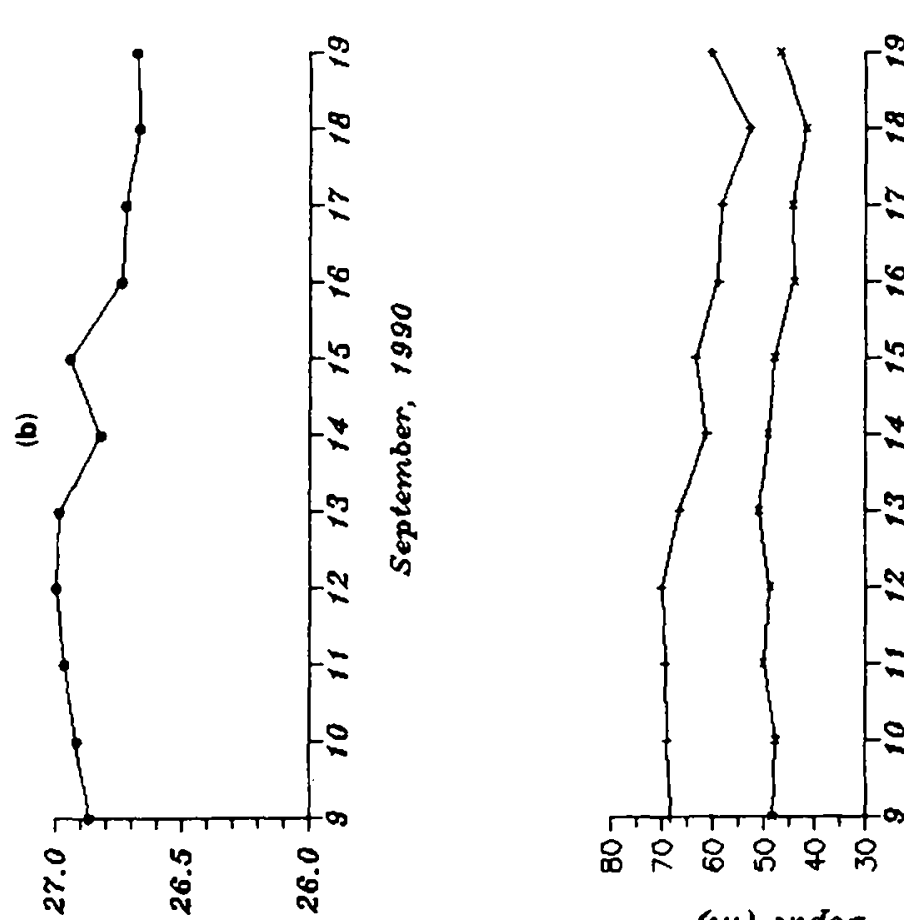

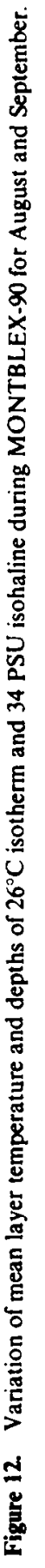
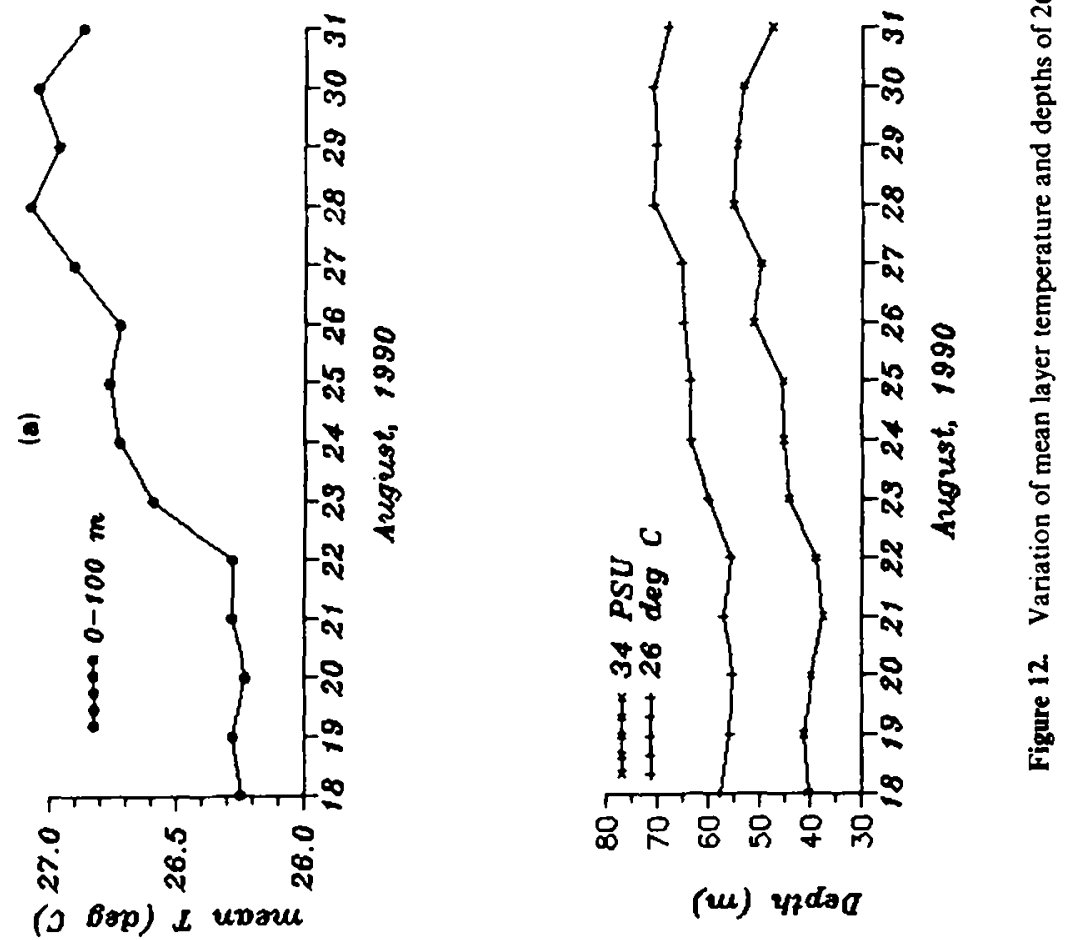

(u) ypda 
support from the estimated heat import during August. The climatological wind stress curl (Hastenrath and Lamb 1979b; Babu 1987; Singh 1993) is positive which is conducive to divergence and hence to upwelling of cold waters. This rules out warm water sinking at the surface during this period. Hence, it can be inferred that the observed warming of the upper layers is due to the movement/advection of a warm core eddy (anticyclonic rotation) during 22nd August - 13th September towards the study location. The occurrence of peak values of depths of isotherms and isohalines on 28th August indicates that the core of the eddy was present at the study location on that day. Similarly, the decrease in the mean temperature in the upper $100 \mathrm{~m}$, and the shoaling of the $26^{\circ} \mathrm{C}$ isotherm and 34.0 PSU isohaline beyond 13th September together with the estimated heat import during September can be attributed to the movement of the warm core eddy away from the study.location. Earlier studies of Rao et al (1987) based on current meter measurements in the shelf region also infer the presence and movement of warm, less saline anticyclonic eddy in the northwestern Bay of Bengal during the southwest monsoon. However, more field observations are required to substantiate and adequately describe this oceanic feature in the northern Bay of Bengal during the southwest monsoon.

\section{Summary and conclusions}

The analysis of the data at a stationary location in the northern Bay of Bengal during the southwest monsoon of 1990 revealed two prominent events by which the oceanic upper layer characteristics are affected. Firstly, the intense subsurface upwelling of colder waters from a depth of $100 \mathrm{~m}$ is noticed during the development of deep depression at a distance of about $150 \mathrm{~km}$ from the study area from 18th to 20th August. The effect of depression-induced upwelling, however, has reached up to the base of the surface homogeneous layer. Because of this, the observed changes in SST are not large during the development period of deep depression. It is also highlighted that active air-sea interaction with positive feed-back from the sea to air prevailed during the development of deep depression wherein the heat loss from the surface layer is utilized to enhance the latent heat flux. Secondly, the advection of a warm core eddy, characterized by relatively less saline waters at its centre, towards the study area is inferred from the gradual increase of mean temperature of the upper layer, mixed layer thickness, and depths of the $26.0^{\circ} \mathrm{C}$ isotherm and $34.0 \mathrm{PSU}$ isohaline from $22 \mathrm{nd}$ August to 13th September with the eddy centre at the study location on 28th August. The net heat loss from the upper layer during September without significant changes in the surface heat fluxes (when compared to August values) is then due to the movement of the eddy away from the study location on 13th September, which might also be aided by the passing low during 12th -13 th September. The lateral advective processes affecting the ocean boundary layer characteristics of the study area by bringing in heat during August and removing it during September are then clearly due to the presence and movement of the warm core eddy (through the study area) during the southwest monsoon - an important feature that has emerged from the MONTBLEX-90 programme in the northern Bay of Bengal. In order to adequately describe this oceanic feature and understand its role on the oceanic boundary layer characteristics more field observations in the northern Bay of Bengal during the southwest monsoon are suggested. 


\section{Acknowledgements}

The authors are grateful to the Director, NIO for his support and are thankful to the Department of Science and Technology, New Delhi for sanctioning a grant-in-aid project under MONTBLEX programme. The authors express their sincere thanks to the anonymous reviewers for their critical comments on the manuscript towards improvement of the paper.

\section{References}

Anon 1990 Oceanographic and meteorological data report of ORV Sagarkanya cruise 56(MONTBLEX-90), National Institute of Oceanography, Dona Paula, Goa

Babu M T 1987 Hydrography and circulation of the waters of Bay of Bengal during post monsoon season; M.Sc. thesis, University of Bombay, Bombay p. 78 (unpublished)

Babu M T, Prasannakumar S and Rao D P 1991 A subsurface cyclonic eddy in the Bay of Bengal; J. Mar. Res. 49 403-411

Chen C T and Millero F J 1977 Speed of sound in sea water at high pressures; J. Acoust. Soc. Am. 62 1129-1135

Cutler A N and Swallow J C 1984 Surface currents of the Indian Ocean (To $20^{\circ} \mathrm{S}, 100^{\circ} \mathrm{E}$ ): Compiled from historical data archived by Meteorological Office; Bracknell, U.K., International Oceanographic Sciences Report No. 187 pp. 36 charts

Emery W J 1975 The role of vertical motion in the heat budget of the upper ocean; Ph.D. dissertation, Hawa.i Institute of Geophysics, University of Hawaii, USA, $81 \mathrm{pp}$.

Gupta M G 1990 Brief report from Monsoon Trough Boundary Layer Experiment Operations Control Centre (MOCC), India Meteorological Department, New Delhi.

Gopalakrishna V V, Murty V S N, Sarma M S S and Sastry J S 1993 Thermal response of upper layers of Bay of Bengal to forcing of a severe cyclonic storm - A case study; Indian J. Mar. Sci. 22 8-11

Hastenrath S and Lamb P J 1979a Climatic atlas of the Indian Ocean. Part II - The oceanic heat budget; University of Wisconsin Préss, Wisconsin 93 charts

Hastenrath S and Lamb P J 1979b Climatic atlas of the Indian Ocean. Part I-Surface climatic and Atmospheric circulation; University of Wisconsin Press, Wisconsin 97 charts

Murty V S N, Sarma Y V B, Rao D P and Murty C S 1992 Water characteristics, mixing and circulation in the Bay of Bengal during southwest monsoon; J. Mar. Res. 50 207-228

Murty V S N, Rao D P and Sarma Y V B 1993 Variability of the marine boundary layer characteristics in the northern Bay of Bengal during MONTBLEX-90 (Abstract); Presented at the Second Monitoring Workshop on MONTBLEX Research Results held at IITM, Pune during 26-27 March, 1993.

Pollack M J 1954 Static stability parameters in oceanography; J. Mar. Res. 13 101-112

Rao D P and Murty V S N 1992 Variability of temperature and water vapour content in the lower troposphere of the northern Bay of Bengal during MONTBLEX-90; In: Proceedings of workshop on preliminary results of MONTBLEX held at IISc Bangalore during 16-17 January, 1992, DST \& MST, Technology Bhavan, New Delhi, 185 pp

Rao K H, Antony M K, Murty C S and Reddy G V 1987 Gyres in the NW Bay of Bengal - Some observed evidences; Indian J. Mar. Sci. 16 9-14

Sarma Y V B, Seetharamayya P and Rao D P 1992 Ocean-atmosphere interaction in the vicinity of monsoon trough over the head of the Bay of Bengal; In: Montblex News - A Bulletin of the MONTBLEX team, Bangalore, 5, January, 1992

Singh O P 1993 Variability of wind stress and wind stress curl over the north Indian Ocean during pre-monsoon and monsoon seasons of 1987 and 1988; Mahasagar-J. of Limnology and Oceanography $269-14$

Suga T and Hanawa K 1990 The mixed layer climatology in the northwestern part of North Pacific subtropical gyre and formation of subtropical mode water; J. Mar. Res. $48543-566$

Swallow J C 1983 Eddies in the Indian Ocean; In Eddies in marine science, (Ed.) A R Robinson (SpringerVerlag, Berlin) p. 200-208 